\title{
TRANSLATION PROCEDURES IN THE TRANSLATION OF ENGLISH ADVERBS OF MANNER(-LY)INTO INDONESIAN
}

\author{
Ni Putu Meri Dewi Pendit \\ IKIP Saraswati \\ penditmeri@yahoo.com
}

\begin{abstract}
Both English and Indonesian have adverb of manner. This part of sentence is used to describe how how an action occurred or to state how an action was taken. English adverbs of manner can be easly seen from the suffix -ly at the end of the word. In the other hand, Indonesian adverbs of mannerare not only in the form of wordbut also prepositional phrase or clause. Data taken from an Indonesian version of English novel indicated that the English adverbs of manner are translated in various ways into Indonesian. Since there are lots of ways in translating the English adverbs of manner, this study was conducted to see the procedure used to translate the English adverbs of manner into Indonesian in the novel Breaking Dawn and its translation Awal yang Baru.
\end{abstract}

Keywords: Adverbs of Manner, Translation Procedures, Source Language (SL), Target Language (TL)

\begin{abstract}
ABSTRAK
Bahasa Inggris dan bahasaIndonesia duaduanyamemiliki kata keterangancara. Bagian kalimat ini digunakan untuk menggambarkan bagaimana suatu tindakan terjadi atau untuk menyatakan bagaimana suatu tindakan dilakukan. Adverbia kecaraan dalam bahasa Inggris dapat dilihat dengan mudah dari akhiran -ly pada kata tersebut. Di sisi lain, keterangan cara dalam bahasa Indonesia tidak hanya dalam bentuk kata juga dapat dalam bentuk frasa preposisional atau klausa. Data yang diambil dari novel Breaking Dawn dan Awal Yang Baru menunjukkan bahwa kata keterangan cara bahasa Inggris diterjemahkan dalam berbagai bentuk dalam bahasa Indonesia. Adanya variasi penerjemah anter sebut, maka studi ini dilakukan untuk melihat prosedur yang digunakan untuk menerjemahkan kata keterangan cara bahasa Inggris ke dalam bahasa Indonesia dalam novel Breaking Dawn dan terjemahannya Awal yang Baru.
\end{abstract}

Kata kunci: Kata Keterangan Cara, ProsedurPenerjemahan, Bahasa Asal (SL), Bahasa Target $(T L)$

\section{INTRODUCTION}

In this globalization era, many people are trying to be able to master more than one foreign language. Language is the first tool in order to see the world and to be famous world wide. It seems that being a foreign language teacher or a translator is a good choice. Observation and research on languages also need to be conducted. It is used to get the best equivalence of the source language to the target language. One of the interesting parts in English is adverbs of manner. Therefore, this study aimed at finding out the procedure of translation apllied in the translation of English adverbs of manner (-ly) into Indonesian in the novel Beraking Dawn and Awal Yang Baru. 
English adverbs of manner are often formed by adding -ly to adjectives and placed after the main verb or after the object. For example, great yields greatly, and beautiful yields beautifully. In Indonesia, an adverb of manner is called adverbiakecaraan. Alwiet all. (2008: 205) imply that adverb of manner is anadverbthatdescribes themeaningrelated with howthe event described by the adverb occurs for example: seenaknya, secepatnya, sepenuhnya, dengancepat, secaralambatortanpa, etc. It becomes interesting how the strategies or procedures apllied in the translation of English adverbs of manner (-ly) into Indonesian. It would be confusing then how they could be best translated into Indonesian.

According to Mailhac (2003), translation procedure is a means of translating a particular element of SL. He also states that a procedure is thus a tool to be exploited in order to solve a translation problem. To the extent that the properties of a tool are determined by its intended use, procedures are goal oriented and, being part of the translational output, they are visible e.g. one can see whether a culture-specific term has been borrowed, defined in a footnote, etc. in the translation (Mailhac, 2003).

In this study, translation procedure is defined as a means of translating a particular element of the Source Language (SL) into Target Language (TL). The particular element analyzed in this study is adverbs of manner (end with -ly) in English. In other words, the translation procedures being analyzed in this study are means or tool used by the translator to translate the English adverbs of manner into Indonesian. The translation procedures wereanalyzed through the data on both of the novels.

\section{RESEACH METHOD}

The data in this study was taken from two novels. First, it is an English novel written by Stephenie Meyer (2008) entitled Breaking Dawn. The second novel is the Indonesian version of BreakingDawn, Awal yang Baru translated by Monica DwiChresnayani (2009). The adverbs of manner collected here were only the adverbs of manner which end with $-l y$. Both of the novels consist of 39 chapters. There are 754 pages on the original novel and 864 pages on the Indonesian version.

The adverbs of manner in the SL novel were documented as well as their translation in TL novel. The results of the translation were grouped and analyzed based on its procedure of translation. The adverbs of manner in the SL and TL sentence were underlined and put side by side in a table. They were analyzed qualitatively using the theory of translation procedures by Vinay and Darbelnet (2000).

\section{DISCUSSION}

There were two kinds of translation strategies found: direct and oblique translations. In the direct translation strategy, there was only one translation procedure found. That was borrowing. Then, in the oblique translation strategy, there was also only one procedure found. That was transposition procedure. Hence, there were two translation procedures used to translate the English adverbs of manner into indoneian. The procedures were transposition and borrowing. Transposition is part of the oblique translation strategy and borrowing is part 
of the direct translation strategy. Those procedures were analysed from the English adverbs of manner (ending with ly) and their translations in Indonesian. The different word ranks between SL and $\mathrm{TL}$ indicated that there was a transposition procedure. The English adverb of manner which its base word was taken directly for the result of translation in Indonesian was referred to as borrowing procedure.

Direct translation is used when structural and conceptual elements of the source language could be transposed into the target language. In the direct translation, there are three procedures of translation: Borrowing, Calque, and Literal Translation. Here, it was found that the translation of English adverbs of manner found in this study used borrowing procedure.

As stated previously, borrowing procedure is part of the direct translation strategies. It is used when structural and conceptual elements of the source language could be transposed into the target language. Here, borrowing procedure is whenthe source language word transferred directly to the target language, (Vinay and Darbelnet, 2000 in Munday, 2001: 56). In other words, it was a procedure when a word taken directly from another language.

From the data of this study, the translation of the English adverbs of manner (ending with -ly) into Indonesian depended on the meaning of the base word of the English adverbs of manner. More than half of the total adverbs of manner found in the novel were translated into words. Those words referred to the meaning of the base word of the adverbs of manner. Then, the other translations which were in the form of phrases consisted of preposition, and the meaning of the base word of the adverb of manner, e.g. quickly was derived from an adjective quick meaning cepat in Indonesian. As an adverb of manner, quickly could be translated into cepat or dengancepat. Due to this fact, several base words of the English adverbs of manner were taken directly as the translations into Indonesian. It was naturalized borrowing because only the base word of the English adverb of manner was taken as the translation in Indonesian.

\begin{tabular}{|c|c|}
\hline SL & $\mathrm{TL}$ \\
\hline $\begin{array}{l}\text { Edward suddenly } \\
\text { stiffened and } \\
\text { turned } \\
\text { automatically in } \\
\text { the other } \\
\text { direction, as if } \\
\text { someone had } \\
\text { called his } \\
\text { name.(Page 57) }\end{array}$ & $\begin{array}{l}\text { Tubuh Edward } \\
\text { tiba-tiba tegang } \\
\text { dan otomatis ia } \\
\text { berbalik kearah } \\
\text { lain, seolah-olah } \\
\text { ada yang } \\
\text { memanggil } \\
\text { namanya. (Page } \\
\text { 76) }\end{array}$ \\
\hline $\begin{array}{l}\text { "Why didn't I } \\
\text { think of that?" he } \\
\text { muttered } \\
\text { sarcastically.(Page } \\
111 \text { ) }\end{array}$ & $\begin{array}{l}\text { "Mengapa itu } \\
\text { tidak terpikirkan } \\
\text { olehku?" } \\
\text { gerutunya } \\
\text { sarkastis. (Page } \\
\text { 137) }\end{array}$ \\
\hline $\begin{array}{l}\text { Garret muttered } \\
\text { mysteriously to } \\
\text { himself and then } \\
\text { chuckled once. } \\
\text { (Page 680) }\end{array}$ & $\begin{array}{l}\text { Gumam Garret } \\
\text { misterius pada } \\
\text { dirinya sendiri, } \\
\text { kemudian } \\
\text { terkekeh. (Page } \\
778 \text { ) }\end{array}$ \\
\hline
\end{tabular}

The word automatically was derived from an adjective automatic. Sequencially, sarcastically and mysteriously were derived from adjectives sarcastic and mysterious. Then, their translatons becameotomatis, sarkastis, andmisterius. Even, there were small changes in the written form of the 
borrowed words but the meanings were still the same.

In the data, the borrowed words were also added with preposition dengan or secara.

\begin{tabular}{|c|c|}
\hline SL & TL \\
\hline $\begin{array}{l}\text { Maybe if we can } \\
\text { satisfy it, we'll } \\
\text { be able to help } \\
\text { her more } \\
\text { effectively."(Pag } \\
\text { e 239) }\end{array}$ & $\begin{array}{l}\text { Mungkin kalau } \\
\text { kita bisa } \\
\text { memuaskannya, } \\
\text { kita akan bisa } \\
\text { membantu Bella } \\
\text { dengan lebih } \\
\text { efektif.(Page 283) }\end{array}$ \\
\hline $\begin{array}{l}\text { Rather than } \\
\text { wince away as } \\
\text { her human } \\
\text { thoughts wanted } \\
\text { to, she let her } \\
\text { wolt-self react } \\
\text { instinctively. } \\
\text { (Page 314) }\end{array}$ & $\begin{array}{l}\text { Alih-alih meringis } \\
\text { seperti yang } \\
\text { diinginkan pikiran } \\
\text { manusianya, Leah } \\
\text { membiarkan sosok } \\
\text { srigalanya } \\
\text { bereaksi secara } \\
\text { instingtif. (Page } \\
\text { 366) }\end{array}$ \\
\hline $\begin{array}{l}\text { Though she } \\
\text { doesn't speak- } \\
\text { yet-she } \\
\text { communicates } \\
\text { quite effectively. } \\
\text { (Page 429) }\end{array}$ & $\begin{array}{l}\text { Walaupun tidak } \\
\text { bias bicara-belum- } \\
\text { tetapi dia bias } \\
\text { berkomunikasi } \\
\text { secara efektif. } \\
\text { (Page } 497)\end{array}$ \\
\hline $\begin{array}{l}\text { So, a kind of } \\
\text { victory there, } \\
\text { too, considering } \\
\text { that the volturi } \\
\text { had never been } \\
\text { seriously } \\
\text { challenged in } \\
\text { millennia. (Page } \\
652 \text { ) }\end{array}$ & $\begin{array}{l}\text { Jadi, itu sendiri } \\
\text { sudah merupakan } \\
\text { kemenangan } \\
\text { tersendiri } \\
\text { mengingat } \\
\text { keluarga volturi } \\
\text { tak pernah } \\
\text { ditentang secara } \\
\text { serius dalam satu } \\
\text { abad terakhir. } \\
\text { (Page 745) }\end{array}$ \\
\hline
\end{tabular}

The borrowed words on the data above wereefektif, instingtif, andserius. They were explicitely translated as adverbs of manner due to the additions of prepositiondenganandsecara. Thus, whether they were translated into base word or prepositional phrase, two translation procedures were applaid (transposition and borrowing procedure).

According to Vinay and Darbelnet (2000) in Munday (2001), in cases where literal translation is not possible, oblique translation strategy must be used. It is used when the structural or conceptual elements of the source language could not be directly translated without altering meaning or upsetting the grammatical and stylistic elements of the target language. There are four translation procedures in oblique translation: Transposition, Modulation, Reformulation or Equivalence, and Adaptation. In thisstudy, therewasonly one procedurewhichwasbelong to oblique translation strategy. That was transposition.

Besides using borrowing procedure, there was also transposition procedure in the translation of the English adverbs of manner into Indonesian. Transpositionis a change of one part of speech for another without changing the sense (Munday, 2001:57). There were words, phrases, and clauses in the result of the translation in Indonesian. Those grammatical units in Indonesian were used to modify the verb in the sentence.

There were changes of rank from the SL to TL. The changes of rank were from words (adverbs of manner) to phrases in TL. It also belonged to Vinay and Darbelnet's transposition procedures of translation. There was a replacement of one grammatical form by another grammatical form. The example of this translation was the word overtly which was translated to a prepositional phrase secaraterang-terangan. 


\begin{tabular}{ll}
\multicolumn{1}{c}{ SL } & \multicolumn{1}{c}{ TL } \\
\hline The present it & Hadiah itu sendiri \\
self was not & tidak mengancam \\
overtly & $\underline{\text { secara terang- }}$ \\
threatening. & $\frac{\text { terangan. }}{612)}$ (Page \\
(Page 531) & \\
\hline
\end{tabular}

The last, the adverbs of manner in the SL were translated into clauses in Indonesian. The same as the above procedure of translation, this way of translation was also transposition procedure. Word as a unit of a sentence in SL was changed into clause in TL. Hence, there were changes of rank from SL to TL. The example of this translation was:

\begin{tabular}{ll}
\hline \multicolumn{1}{c}{ SL } & \multicolumn{1}{c}{ TL } \\
\hline "Seth doesn't & "Seth berpendapat \\
think Sam will & Sam tidak akan \\
attack now," & menyerang \\
Edward said & sekarang," kata \\
mechanically. & Edward, suaranya \\
(Page 222) & seperti robot. \\
& (Page 263) \\
\hline
\end{tabular}

The word mechanically above was translated into a clause suaranyaseperti robot. The change of rank was from word (adverbs of manner) to clause in TL. It should be done because it was hard to find other equivalent of this word in the TL that appropriate to be put in the sentence. This was why the translator translated it into clause in order to reach the closest equivalent of this word in TL. Hence, the change of rank here (from words to clauses) was done to deal with the lexical gap by a grammatical structure between SL and TL.It could be concluded that the translations of the adverbs of manner inthe novel Breaking Dawn (SL) to Awal yang Baru(TL) also used transposition procedure. It included the change of rank from the SL to the TL.

\section{CONCLUSION}

The translation procedures applied in the translation ofthe englsihadverbs of manner (ending with -ly) in the novel Breaking Dawn into Target Language Awal yang Baru were transposition and borrowing. There was transposition procedure of translation because there were changes of word rank from SL adverbs of manner into Indonesian (from word to phrases or from word to clauses). The second procedure is borrowing procedure. The base word of the SL adverb of manner is taken directly as its translation in Indonesian.

Each procedure has its own advantages that differ according to the texts under translation. It is up to the translator to choose the procedure which is more practical and helpful in the translation of the SL text. Besides, the translator could only use one procedure, or exceed it to two, three, or even four procedures in the same translated text. Therefore, it seems that there is a movement in the process of translation because the result of translation could be more, or less semantic and communicative.

\section{REFERENCE}

Alwi, Hasan. Dkk. 2008. Tata Bahasa Baku Bahasa Indonesa. Edisi ketiga. Jakarta: Balai Pustaka.

Baker, Molina. 1998. Routledge Encyclopedia of Translation Studies. London: Routledge. 
Bell. Roger. 1991. Translation and Translating: Theory and Practice. New York: Longman.

Biber, Douglas and friends. 2002. Longman Student Grammar of Spoken and Written English. England: Longman.

Brown, Samuelsson. 2004. A Practical Guide for Translators. Toronto: Multilingual Matters Ltd.

Catford, J. C. 1965. A Linguistic Theory of Translation: An Essay in Applied Linguistics. New York: Oxford University Press.

Hatim, Basil and Munday, Jeremy. 2004. Translation. USA: Routledge.

Ordudari, Mahmoud. 2008. Translation Procedures Strategies and Methods. Available from: http://accurapid.com/journal/41cul ture.htm

Munday, Jeremy. 2001. Introducing Translation Studies. Theoris and Application. New York: Routledge.

Schäffner, Christina. 2004. Translation Research and Interpreting Research Traditions, Gaps and Synergies. Toronto: Multilingual Matters Ltd

Susanti, Ira. 2009. An Analysis of Adverbs of Manner in Sidney Sheldon's Morning, Noon and Night and Its Translation into Indonesian by Hendarto Setiadi (Thesis). Retrieved from http://www.repository.usu.ac.id 